\title{
CHARACTERISTICS OF COLUMBIA SPOTTED FROG (RANA LUTEIVENTRIS) OVIPOSITION SITES IN NORTHEASTERN OREGON, USA
}

\author{
Christopher A. Pearl ${ }^{1,2}$, Michael J. Adams ${ }^{1}$, and Wendy H. Wente ${ }^{1}$
}

\begin{abstract}
Several western ranid frogs possess a unique strategy of breeding communally over a short temporal window and reusing oviposition sites between years. However, little is published on the characteristics of oviposition sites selected by these explosive breeders. The Columbia spotted frog (Rana luteiventris) is native to northwestern North America and is of conservation concern in the southern portions of its range. As part of a study examining relationships between livestock grazing and R. luteiventris habitat, we assessed characteristics of the species' oviposition sites in 25 fishless ponds in northeastern Oregon. Oviposition sites were generally in shallow water $(<25 \mathrm{~cm})$ close to shore and tended to be in the northeastern portion of ponds. Oviposition sites were found more frequently over heavily vegetated substrates and in areas of less substrate slope and shade than random points in littoral zones. We did not quantify temperature differences within ponds, but the patterns we documented are consistent with preferential use of warmer microhabitats for oviposition.
\end{abstract}

Key words: Columbia spotted frog, Rana luteiventris, amphibian, breeding, communal, habitat, oviposition, pond, ranid.

Pond breeding amphibians select locations for egg deposition on 2 scales: among accessible aquatic habitats on the landscape and among microhabitats within ponds. Selection among ponds can be influenced by broad factors such as drying risk and the occurrence of predators and competitors (Resetarits and Wilbur 1989, Petranka et al. 1994, Evans et al. 1996, Spieler and Linsenmair 1997). Relatively few studies have addressed selection of oviposition sites within breeding ponds. Knowledge of characteristics of oviposition sites is important for habitat management for sensitive species, particularly for ranids such as the Columbia spotted frog (Rana luteiventris), the Oregon spotted frog (R. pretiosa), and the Cascade frog (R. cascadae) that often deposit eggs communally and reuse oviposition sites among years (Licht 1971, Briggs 1987, Bull and Shepherd 2003, Davis and Verrell 2005).

Rana luteiventris has one of the largest and highest latitude ranges of any North American amphibian, extending from southern Alaska to northern Nevada (Green et al. 1996, Reaser and Pilliod 2005). Declines have been reported in multiple portions of the species' southern range (Patla 1997, Reaser 1997, Reaser and Pilliod 2005, Wente et al. 2005). Despite the recent attention toward $R$. luteiventris, aspects of its ecology and habitat use remain incompletely understood. As a part of a study examining the effects of livestock grazing on $R$. luteiventris breeding habitat, we quantified characteristics of $R$. luteiventris oviposition sites in the Blue Mountains of northeastern Oregon, USA. We compared attributes of oviposition sites to randomly generated points to assess which variables are potentially preferred by $R$. luteiventris for oviposition microhabitat.

\section{STUDY AREA}

We studied $R$. luteiventris oviposition at ponds in the Burnt River $(n=20)$ and Powder River $(n=5)$ drainages of northeastern Oregon. We selected study ponds where we had found $R$. luteiventris but not fish during visual or trapping surveys in previous years. Ponds ranged from 1340 to $1790 \mathrm{~m}$ in elevation and from 105 to $5625 \mathrm{~m}^{2}$ in surface area. Maximum depths were $<1 \mathrm{~m}$ ( $n=8$ ponds), $1-2 \mathrm{~m}$ $(n=9)$, or $>2 \mathrm{~m}(n=8)$. Study ponds had anthropogenic $(n=21)$ and natural $(n=4)$ origins. This distribution of pond types is typical in our study region where beaver numbers are reduced from historical levels and where ponds associated with livestock grazing and mining operations are relatively common.

${ }^{1}$ USGS Forest and Rangeland Ecosystem Science Center, 3200 SW Jefferson Way, Corvallis, OR 97331

${ }^{2}$ E-mail: christopher_pearl@usgs.gov 
Yearly precipitation in this region is $30-60 \mathrm{~cm}$ (greater at higher elevations) and falls mainly as snow between November and March (Franklin and Dyrness 1973).

\section{Methods}

We surveyed study ponds every 3-8 days during the breeding season of $R$. luteiventris in early spring (April-May) 2003. During each visit, teams of 2-3 surveyors carefully searched for egg masses in all areas $<1 \mathrm{~m}$ deep. We counted, mapped, and noted Gosner stage (Gosner 1960) for each egg mass in all oviposition sites so that we could determine when new masses were deposited. Rana luteiventris is an explosive breeder (sensu Wells 1977) and females often deposit egg masses communally (in contact with one another). We considered oviposition sites independent if they were separated by $>20 \mathrm{~cm}$ (the diameter of a large egg mass). We quantified environmental variables at each oviposition site at the center of each cluster of egg masses. We used random points in littoral zones to characterize conditions available to $R$. luteiventris in our study ponds. We identified locations of these points by randomly selecting a compass angle from the center of each pond $\left(0^{\circ}-359^{\circ}\right)$ and a distance from shore $(0-200 \mathrm{~cm})$. This $200-\mathrm{cm}$ distance was derived from our observations at other sites and literature suggesting that $R$. luteiventris deposits eggs close to shore. For example, egg masses were an average of $1.4 \mathrm{~m}$ from shore in Utah (Cuellar 1994) and $1.17 \mathrm{~m}$ from shore elsewhere in Oregon (Bull and Marx 2002). We generated at least 3 random points for each pond and added 1 random point for each $R$. luteiventris oviposition site above 3.

At each random point and $R$. luteiventris oviposition site (when first detected), we quantified distance from shore, compass angle to pond center, water column depth, substrate slope, horizon shading, vegetation density, and dominant vegetation taxon. Water depth $(\mathrm{cm})$ and distance to shore $(\mathrm{m})$ were measured with a 2-m rod. Distance to shore was measured perpendicular to the nearest shoreline. We recorded the dominant vegetation taxon and categorized the density of vegetation as sparse $(<25 \%$ of substrate covered), moderate $(25 \%-$ $75 \%)$ or dense $(>75 \%)$ within a 1 -m-diameter circle centered on the oviposition site or ran- dom point. We estimated substrate slope (\%) by measuring depth change over a $2-\mathrm{m}$ transect perpendicular to shore with the oviposition site or random point at the transect midpoint. To quantify shading, we used a clinometer to measure the angle to the horizon or to the top of anything obscuring the horizon (e.g., forest, ridgelines) while facing $90^{\circ}$ (East), $120^{\circ}, 150^{\circ}$, $180^{\circ}$ (South), $210^{\circ}, 240^{\circ}$ and $270^{\circ}$ (West). These angles were averaged into 1 value per oviposition site or random point.

\section{Statistical Analyses}

To compare water column depth, substrate slope, and horizon shading between oviposition and random sites, we used paired, 2-tailed $t$ tests on means within ponds. To compare vegetation density between oviposition sites and random points across all ponds, we used a chi-square test on counts of sites in each of the 3 density classes (sparse, moderate, and dense). We used Rayleigh's test (Zar 1999) to examine whether oviposition sites were uniformly distributed with respect to compass angle from the middle of ponds. We used linear regression to examine the predictive value of (1) number of oviposition sites on total egg masses per pond, (2) pond size on number of oviposition sites per pond, and (3) pond size on number of egg masses per pond. Pond size was natural $\log$ transformed for analysis. We considered tests significant if $P<0.05$. We used SYSTAT 10.2 (SYSTAT Software, Inc. 2002) for all statistical summaries and tests with the exception of the Rayleigh's test, which was conducted with Oriana 2.00 software (Kovach Computing Services, Inc.).

\section{Results}

We collected environmental data from 83 R. luteiventris oviposition sites and 97 random points. We detected $3.32 \pm 0.38\left(\bar{x} \pm s_{\bar{x}}\right.$ for all results) oviposition sites per pond (range 1-8), and oviposition sites averaged $3.65 \pm 0.48 \mathrm{egg}$ masses (range 1-21). Thirty-nine of 83 oviposition sites (47\%) were single egg masses; these accounted for $12.9 \%$ of the total egg masses deposited in all ponds (Fig. 1). We detected an average of $12.12 \pm 1.62$ egg masses per pond (range 1-30).

Oviposition sites in our ponds averaged $1.10 \pm 0.12 \mathrm{~m}$ (range 0.08-6.20 m) from shore. Mean water depth at oviposition sites was 


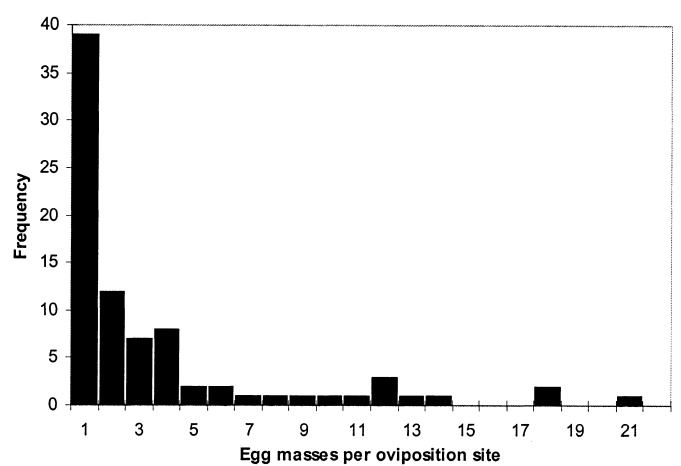

Fig. 1. Numbers of Rana luteiventris egg masses per oviposition site in 25 ponds in northeastern Oregon.

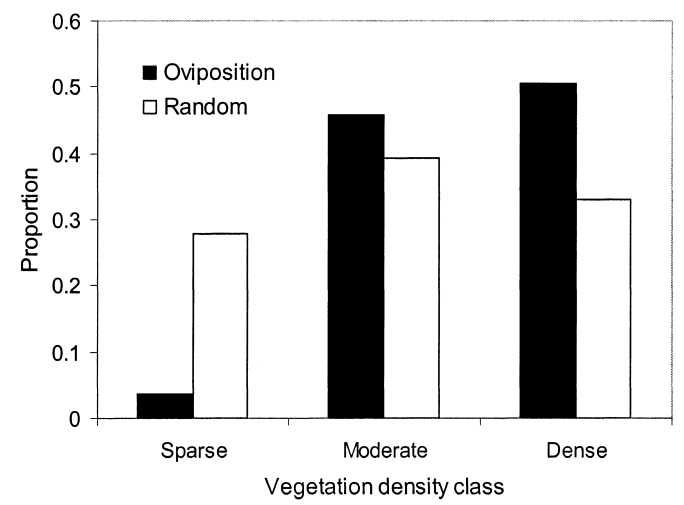

Fig. 2. Proportion of Rana luteiventris oviposition sites $(n=83)$ and random sites $(n=97)$ in sparse $(<25 \%)$, moderate $(25 \%-75 \%)$ and dense $(>75 \%)$ vegetation.

$13.00 \pm 0.79 \mathrm{~cm}$ (range $5-44 \mathrm{~cm})$ and was less than at random points $(30.31 \pm 2.77 \mathrm{~cm}$; $t=$ -4.64 , df $=24, P<0.001)$. Oviposition sites were less sloped $(16.58 \% \pm 1.72 \%)$ than random points $(32.47 \% \pm 3.21 \% ; t=-4.509$, df $=24$, $P<0.001)$ and were in positions with less horizon shading $\left(23.88^{\circ} \pm 1.85^{\circ}\right)$ than random points $\left(29.90^{\circ} \pm 2.10^{\circ} ; t=-4.244\right.$, df $=24, P$ $<0.001)$.

Oviposition sites were rarely found in areas with $<25 \%$ vegetation ( 3 of 83 sites; Fig. 2 ) and were disproportionately found in areas with $>75 \%$ vegetative cover $\left(\chi^{2}=19.58, \mathrm{df}=\right.$ $2, P<0.001)$. We found $77 \%$ of $R$. luteiventris oviposition sites above Eleocharis, Carex, Glyceria, and other grasses (Table 1). Bearings of oviposition sites were nonrandomly distributed (Rayleigh's $Z=5.115, P=0.006$ ), and
TABLE 1. Dominant vegetation taxon in 1-m-diameter plots centered on Rana luteiventris oviposition sites $(n=$ 83) or random points $(n=97)$.

\begin{tabular}{lcc}
\hline & \multicolumn{2}{c}{ Frequency } \\
\cline { 2 - 3 } Dominant vegetation taxon & $\begin{array}{c}\text { Oviposition } \\
\text { sites }\end{array}$ & $\begin{array}{c}\text { Random } \\
\text { points }\end{array}$ \\
\hline Spikerush (Eleocharis sp.) & 26 & 18 \\
Sedge (Carex sp.) & 15 & 12 \\
Other grasses (Poaceae) & 12 & 8 \\
Mannagrass (Glyceria sp.) & 11 & 3 \\
Buttercup (Ranunculus sp.) & 5 & 8 \\
Algae & 3 & 10 \\
Rush (Juncus sp.) & 3 & 0 \\
Cattail (Typha sp.) & 2 & 3 \\
Aquatic moss (Fontinalis sp.) & 1 & 4 \\
Unidentified vegetation & 1 & 3 \\
Willow (Salix sp.) & 1 & 1 \\
Pondweed (Potamogeton sp.) & 1 & 0 \\
None (bare substrate) & 2 & 27 \\
\hline
\end{tabular}

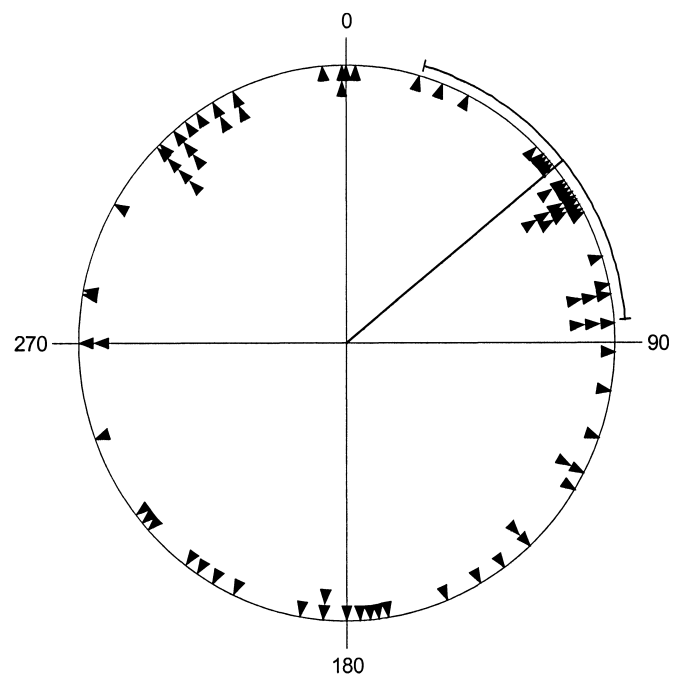

Fig. 3. Angles from pond centers for Rana luteiventris oviposition sites $(n=83)$. The mean vector $(\mu)$ was $50.8^{\circ}$, and the $95 \%$ C.I. was $16.2^{\circ}-85.4^{\circ}$.

the mean angle $(\mu)$ was $50.8^{\circ}(95 \%$ C.I. $=$ $16.2^{\circ}-85.4^{\circ}$; Fig. 3). We found most oviposition sites $(39.7 \%)$ in the northeast quadrant of study ponds, with smaller concentrations in the northwest (25.3\%), southeast $(19.3 \%)$ and southwest $(15.7 \%)$ quadrants.

The number of oviposition sites per pond was a significant predictor of total egg masses per pond $\left(R^{2}=0.24, F=7.49, P=0.012\right)$. Pond surface area was a significant predictor 


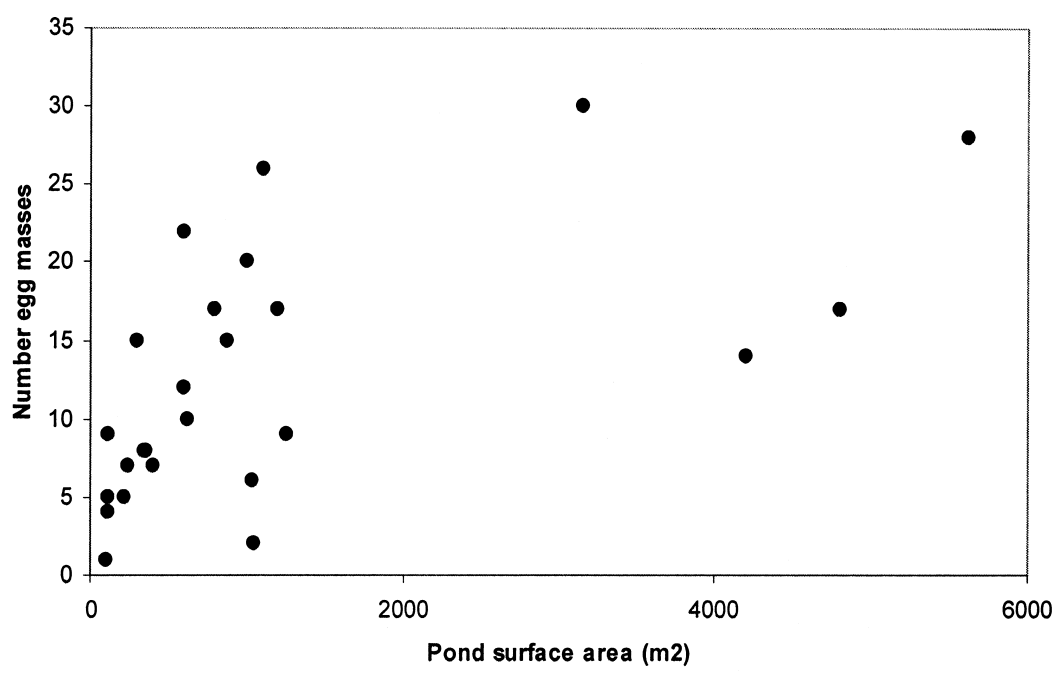

Fig. 4. Number of Rana luteiventris egg masses and pond surface area $\left(\mathrm{m}^{2}\right)$ for 25 ponds in northeastern Oregon.

of both the total number of oviposition sites $\left(R^{2}=0.20, F=5.75, P=0.025\right)$ and number of egg masses $\left(R^{2}=0.45, F=18.96, P<\right.$ 0.001; Fig. 4).

\section{Discussion}

Our study appears to be the first to compare sites used for oviposition with general conditions available to breeding $R$. luteiventris. Consistent with observations from other parts of its range (Cuellar 1994, Bull and Shepherd 2003, Davis and Verrell 2005), $R$. luteiventris in our study area oviposited in shallow water close to shore: $88 \%$ (73 of 83) of oviposition sites were in water $<20 \mathrm{~cm}$ deep and $84 \%$ (70 of 83 ) were $<2 \mathrm{~m}$ from shore. Oviposition sites were associated with low shading along southern horizons and substrates of more gradual slopes and greater vegetation density. We also found that $R$. luteiventris oviposition sites were concentrated in northeastern portions of ponds, with a smaller concentration in northwestern portions. We did not measure water temperature gradients, but each of these habitat characteristics is likely to be associated with warmer areas within breeding ponds.

Other things being equal, northern shorelines of ponds at our latitude should receive the most sun in the early spring when $R$. luteiventris is breeding. Major oviposition sites of another high-latitude, communally breeding ranid (R. sylvatica) were located in warmer areas in Pennsylvania ponds (Seale 1982). Both calling males and oviposition sites of $R$. lessonae tracked warm water around the northern shores of 1 breeding pond in Sweden (Sjogren et al. 1988). Warmer water temperatures likely influence initiation and location of oviposition by $R$. luteiventris and its close relative $R$. pretiosa, which oviposits in similar microhabitats (Morris and Tanner 1969, Licht 1971, Bull and Shepherd 2003). Warmer temperatures accelerate egg development in $R$. luteiventris and R. pretiosa (Johnson 1965, Licht 1971, Bull and Shepherd 2003). Both $R$. luteiventris and $R$. pretiosa have been observed depositing eggs in morning and early afternoon (Licht 1971, Bull and Shepherd 2003, C.A. Pearl personal observation). Ovipositing early in the day may facilitate rapid egg development in warmer daytime waters prior to nighttime cooling (Licht 1971), which can be pronounced in shallow oviposition sites (Bull and Shepherd 2003).

Rana luteiventris oviposition sites in our study ponds tended to be situated among moderate to dense spikerush, sedges, and hydrophytic grasses. Emergent vegetation has been identified as a predictor of $R$. luteiventris breeding in Idaho (Monello and Wright 1999), Oregon (Bull and Marx 2002), and Utah (Welch and MacMahon 2005). Vegetated shallows warm more rapidly than deeper areas, reach higher maximum temperatures, and provide 
quality feeding and refuge areas for other anuran larvae (e.g., Licht 1971, Kupferberg 1997, Alvarez and Nicieza 2002, Baber and Babbitt 2004). Western toads (Bufo boreas), which cooccur with $R$. luteiventris in our study area, often oviposit communally in open, gently sloping shallows around the northern shores of lakes and ponds (Carey et al. 2005, Pearl personal observation). Ponds and lakes with shallowly sloped vegetated benches along their north shores may thus be of particular value as breeding habitat for these amphibians. These shallows also come with risk of desiccation, and both $R$. luteiventris and B. boreas can lose their reproductive effort in years of insufficient flooding or rapid water-level recession (Carey et al. 2005, Davis and Verrell 2005).

The habit of R. luteiventris (Bull and Shepherd 2003, Davis and Verrell 2005) and other explosive communal breeding ranids (e.g., $R$. sylvatica [Seale 1982] and R. pretiosa [Pearl personal observation]) to reuse oviposition sites in most years emphasizes the potential importance of these sites to local population persistence. Where conservation of $R$. luteiventris populations is a concern, we recommend that habitat construction or restoration plans prioritize shallowly sloping benches around northeastern portions of ponds. Factors such as nonnative plant invasion (e.g., reed canarygrass, Phalaris arundinaceae), human recreation, or excessive livestock use have potential to modify these preferred oviposition microhabitats. Based on results from our study and work in Idaho (Monello and Wright 1999), we suggest that anthropogenic ponds can provide breeding habitat for $R$. luteiventris if they possess shallowly sloped, vegetated benches.

\section{ACKNOWLEDGMENTS}

This work was supported by grants from the U.S. Fish and Wildlife Service (Idaho and Oregon State Offices) and the USGS Amphibian Research and Monitoring Initiative (ARMI). We particularly thank A. Kuehl and S. Lisle of the Wallowa National Forest for housing and logistical support. We thank B. McCreary, P. Mueller-Warrant, K. Robinson, and B. Hasty for their careful work in the field. J. Bowerman, E. Bull, B. Hossack, and 2 anonymous reviewers provided helpful comments on the manuscript. Work was conducted under a scientific collecting permit from the Oregon Depart- ment of Fish and Wildlife and with approval from the Oregon State University Animal Care Commission.

\section{Literature Cited}

Alvarez, D., AND A.G. Nicieza. 2002. Effects of temperature and food quality on anuran larval growth and metamorphosis. Functional Ecology 16:640-648.

BABER, M.J., AND K.J. BABBiTT. 2004. Influence of habitat complexity on predator-prey interactions between the fish (Gambusia holbrooki) and tadpoles of Hyla squirella and Gastrophryne carolinensis. Copeia 2004: 173-177.

BRIGGS, J.L., Sr. 1987. Breeding biology of the Cascade frog, Rana cascadae, with comparisons to $R$. aurora and R. pretiosa. Copeia 1987:241-245.

Bull, E.L., AND D.B. MaRX. 2002. Influence of fish and habitat on amphibian communities in high elevation lakes in northeastern Oregon. Northwest Science 76:240-248.

Bull, E.L., AND J.F. SHEPHERD. 2003. Water temperature at oviposition sites of Rana luteiventris in northeastern Oregon. Western North American Naturalist 63: 108-113.

Carey, C., P.S. Corn, M.S. Jones, L.J. Livo, E. Muths, and C.W. Loeffler. 2005. Factors limiting the recovery of boreal toads (Bufo b. boreas). Pages 222-236 in M.J. Lannoo, editor, Amphibian declines: the conservation status of United States species. University of California Press, Berkeley. 1094 pp.

Cuellar, O. 1994. Ecological observations on Rana pretiosa in western Utah. Alytes 12:109-121.

Davis, A.B., And P.A. Verrell. 2005. Demography and reproductive ecology of the Columbia spotted frog (Rana luteiventris) across the Palouse. Canadian Journal of Zoology 83:702-711.

Evans, M., C. YÁBER, AND J.-M. Hero. 1996. Factors influencing choice of breeding site by Bufo marinus in its natural habitat. Copeia 1996:904-912.

FrankLIN, J.F., AND C.T. Dyrness. 1973. Natural vegetation of Oregon and Washington. Oregon State University Press, Corvallis. 452 pp.

Gosner, K.L. 1960. A simplified table for staging anuran embryos and larvae with notes on identification. Herpetologica 16:183-190.

Green, D.M., T.F. Sharbel, J. Kearsley, and H. Kaiser. 1996. Postglacial range fluctuation, genetic subdivision and speciation in the western North American spotted frog complex, Rana pretiosa. Evolution 50: 374-390.

Johnson, O.W. 1965. Early development, embryonic temperature tolerance and rate of development in Rana pretiosa luteiventris Thompson. Doctoral dissertation, Oregon State University, Corvallis. 74 pp.

KupferberG, S.J. 1997. Facilitation of periphyton production by tadpole grazing: functional differences between species. Freshwater Biology 37:427-439.

LICHT, L.E. 1971. Breeding habits and embryonic thermal requirements of the frogs, Rana aurora aurora and Rana pretiosa pretiosa, in the Pacific Northwest. Ecology 52:116-124.

Monello, R.J., And R.G. Wright. 1999. Amphibian habitat preferences among artificial ponds in the Palouse 
region of northern Idaho. Journal of Herpetology 33: 298-303.

Morris, R.L., AND W.W. Tanner. 1969. The ecology of the western spotted frog, Rana pretiosa pretiosa Baird and Girard: a life history study. Great Basin Naturalist 29:45-81.

Patla, D.A. 1997. Changes in a population of spotted frogs in Yellowstone National Park between 1953 and 1995: the effects of habitat modification. Master's thesis, Idaho State University, Pocatello. 215 pp.

Petranka, J.W., S.J. Boone, M.E. Hopey, S.D. Baird, and B. Jennings. 1994. Breeding habitat segregation of wood frogs and American toads: the role of interspecific tadpole predation and adult choice. Copeia 1994:691-697.

Reaser, J.K. 1997. Amphibian declines: conservation science and adaptive management. Doctoral dissertation, Stanford University, Stanford, CA. 148 pp.

Reaser, J.K., and D.S. Pilliod. 2005. Rana luteiventris, Columbia spotted frog. Pages 559-563 in M.J. Lannoo, editor, Amphibian declines: the conservation status of United States species. University of California Press, Berkeley. 1094 pp.

Resetarits, W.J., JR., AND H.M. Wilbur. 1989. Choice of oviposition site by Hyla chrysoscelis: role of predators and competitors. Ecology 70:220-228.
SEALE, D.B. 1982. Physical factors influencing oviposition by the woodfrog, Rana sylvatica, in Pennsylvania. Copeia 1982:627-635.

Sjogren, P., J. Elmberg, and S.-A. Berglind. 1988. Thermal preference in the pool frog Rana lessonae: impact on the reproductive behavior of a northern fringe population. Holarctic Ecology 11:178-184.

SPIEler, M., AND K.E. Linsenmair. 1997. Choice of optimal oviposition sites by Hoplobatrachus occipitalis (Anura: Ranidae) in an unpredictable and patchy environment. Oecologia 109:184-199.

Welch, N.E., AND J.A. MacMahon. 2005. Identifying habitat variables important to the rare Columbia spotted frog in Utah (U.S.A.): an information-theoretic approach. Conservation Biology 19:473-481.

WeLls, K. 1977. The social behavior of anuran amphibians. Animal Behavior 25:666-693.

Wente, W.H., M.J. Adams, and C.A. Pearl. 2005. Evidence of decline for Bufo boreas and Rana luteiventris in and around the northern Great Basin, western USA. Alytes 22:95-108.

ZAR, J.H. 1999. Biostatistical analysis. 4th edition. PrenticeHall, Inc., Upper Saddle River, NJ. 663 pp.

Recieved 22 November 2005 Accepted 3 January 2007 